American Journal of Infectious Diseases 4 (1): 41-49, 2008

ISSN 1553-6203

(C) 2008 Science Publications

\title{
Anti-Platelet and Anti-Endothelial Cell Autoantibodies in Vietnamese Infants and Children with Dengue Hemorrhagic Fever
}

\author{
${ }^{1}$ Nguyen Thanh Hung, ${ }^{1}$ Nguyen Trong Lan, ${ }^{2}$ Yee-Shin Lin, ${ }^{1}$ Chiou-Feng Lin, ${ }^{1}$ Le Bich Lien, ${ }^{2}$ Kao-Jean \\ Huang, ${ }^{3}$ Trai-Ming Yeh, ${ }^{4}$ Do Quang Ha, ${ }^{4} \mathrm{Vu}$ Thi Que Huong, ${ }^{3}$ Lien-Cheng Chen, \\ ${ }^{6}$ Lam Thi My, Jyh-Hsiung Huang, ${ }^{7}$ Ching-Chuan Liu and ${ }^{2}$ Huan-Yao Lei \\ ${ }^{1}$ Department of Dengue Hemorrhagic Fever, Children's Hospital No.1- Ho Chi Minh City, Vietnam \\ ${ }^{2}$ Department of Microbiology and Immunology \\ ${ }^{3}$ Department of Medical Technology \\ ${ }^{4}$ Arbovirus Laboratory, Pasteur Institute- Ho Chi Minh City, Vietnam \\ ${ }^{5}$ Division of Research and Diagnosis, Center for Disease Control, Department of Health, \\ Taipei, Taiwan, Republic of China \\ ${ }^{6}$ Department of Pediatrics, University of Medicine and Pharmacy- Ho Chi Minh City, Vietnam \\ ${ }^{7}$ Department of Pediatrics, College of Medicine, National Cheng Kung University, \\ Tainan, Taiwan, Republic of China
}

\begin{abstract}
Dengue hemorrhagic fever (DHF) is a serious public health problem. Increased vascular permeability and thrombocytopenia are the hallmarks of DHF. The mechanisms involved in DHF/Dengue shock syndrome (DSS) pathogenesis is not fully understood. This study gives evidence of the presence of antibodies which cross-reacted with platelets, and endothelial cells in the sera of Vietnamese infants and children with DHF/DSS. The anti-platelet, anti-endothelial cell IgM levels were higher in the sera of DHF/DSS infants and children, compared with controls. However, the levels of these autoantibodies were not correlated with the severity of DHF (non-shock DHF vs DSS). The antiplatelet, and anti-endothelial cell autoantibodies may play a role in the pathogenesis of DHF/DSS in infants and children with predominantly primary, and secondary dengue infections, respectively. The epitopes shared by surface molecules of platelets and endothelial cells and dengue virus antigens need to be identified and avoided in designing the safe candidate vaccines.
\end{abstract}

Key words: Dengue hemorrhagic fever, infants, children, autoantibody, endothelial cells, platelets

\section{INTRODUCTION}

Dengue hemorrhagic fever (DHF)/dengue shock syndrome (DSS) caused by dengue virus infection is a serious public health problem worldwide $^{[1,2]}$. An estimated 50 million infections occur annually, including 500,000 cases of DHF/ DSS, at least $2.5 \%$ of cases $\mathrm{die}^{[3]}$. Increased vascular permeability and thrombocytopenia are the hallmarks of the disease ${ }^{[1,2,4,5]}$. The immunopathogenesis of dengue virus infection with emphasis on the immune deviation, autoantibodies, and cytokine production has been proposed ${ }^{[6]}$. It is possible that capillary endothelial cells may mediate the vascular leakage. Although dengue virus replicates readily in cultures of human endothelial cells ${ }^{7-9]}$, however, there is no evidence of necrosis of endothelial cells nor infiltration of inflammatory cells into blood vessel walls in human tissues studied at biopsy or autopsy ${ }^{[4,10]}$. The mechanism of the endothelial barrier disruption leading to plasma leakage in DHF/DSS is not fully known.
Endothelial cell apoptosis induced by dengue virus infection in vitro associated with complement activation, and chemokine production may cause fulminant but transient vascular leakage ${ }^{[8]}$. Lin et al. have reported that antibodies from dengue patients cross-reacted with endothelial cells and induced damage $^{[11]}$. Thrombocytopenia relating to the bleeding tendency is a constant finding in DHF/DSS patients. The presence of autoantibodies which cross-reacted with platelets could be detected in patient sera ${ }^{[12]}$. These first evidence of the presence of anti-endothelial cell and anti-platelet autoantibodies in dengue patients were observed in dengue fever (DF)/ DHF patients from an outbreak in southern Taiwan from November 1998 to January $1999^{[11,12]}$. Whether the presence of autoantibodies in dengue patients is also relevant in dengue endemic countries needs to be elucidated in an attempt to develop the safe candidate vaccines against dengue infections. In this report, we verify the presence of anti-platelet and anti-endothelial cell autoantibodies in DHF/DSS infants and children with predominantly

Correspondence Author: Huan-Yao Lei, Department of Microbiology and Immunology, College of Medicine, National Cheng Kung University, Tainan, Taiwan, Republic of China 
primary, and secondary dengue infections, respectively, in southern Vietnam where is an endemic region of dengue virus infections. We also gives evidence of in vivo endothelial cell damage demonstrated by elevated levels of thrombomodulin in the sera of these patients.

\section{MATERIALS AND METHODS}

Patients: Fifty infants, ages less than 12 months, admitted to the Department of Dengue Hemorrhagic Fever, Children's Hospital N.1- Ho Chi Minh City from May, 1998 to March, 2002, and 37 children, ages of 415 years, admitted from September to November, 2001 with clinical diagnosis of DHF/DSS according to the criteria of the World Health Organization ${ }^{[2]}$ which were confirmed by positive viral envelope and membrane (E/M)-specific capture IgM and IgG enzyme-linked immunosorbent assays (ELISA) were enrolled in the study. Informed consent was obtained from all parents or guardians. The study was approved by the Scientific and Ethical Committee of Children's Hospital No.1HCM City.

Sample collection: Paired blood samples were collected from each patient in the study, one acute and one convalescent. Acute blood sample, 2-3 mL, was obtained at the admission (day 3 to day 7 after the onset of fever). Convalescent blood sample, 2-3mL, was obtained in the convalescent phase (day 8 to day 19 after the onset of fever). The samples were separated as quickly as possible and stored at $-70^{\circ} \mathrm{C}$ until used.

Laboratory methods: Complete blood counts were performed by Careside H-2000 counter at the hospital laboratory. Dengue infections in the patients were confirmed by viral E/M-specific capture $\operatorname{IgM}$ and IgG ELISA using dengue virus and Japanese encephalitis (JE) virus as antigens at the Center for Disease Control (CDC), Department of Health, Taipei, Taiwan. Capture IgM and IgG ELISA using diluted pooled virus antigens from culture supernatants of 4 serotypes of dengue virus (DEN-1, DEN-2, DEN- 3, and DEN-4), and JE virus-infected Vero cells as antigens was performed to measure the $\operatorname{IgM}$ and $\operatorname{IgG}$ antibodies from paired sera of the patients. The enzyme activity was finally developed and the optical density (OD) was determined $30 \mathrm{~min}$ later at the dual wavelengths of 405 and $630 \mathrm{~nm}$ with a Dynatech MR700 microplate reader $^{[13,14]}$. NS1 serotype-specific IgG ELISA using diluted NS1-containing culture supernatants of DEN-1-, DEN-2-, DEN-3-, DEN-4- or JE virus-infected Vero cells as antigens was performed to measure the NS1specific IgG antibody from the sera of the patients ${ }^{[13,14]}$. The ODs read from culture supernatants of Vero cells with or without dengue virus infection were designated the test absorbance and negative control value for each sample in the ELISA. Positivity was determined by comparison to individual negative controls. A positive sample was defined as having a test absorbance/negative control ratio of $\geq 2.0$, and a negative sample was defined as having a ratio of $<2.0$. For those sera with positive capture $\operatorname{IgM}$ and $\operatorname{IgG}$ ELISA, IgM/IgG ratio $\geq 1.2$ defined a primary dengue infection, and a ratio $<1.2$ defined a secondary dengue infection. For those sera with positive NS1-specific IgG antibody responses, NS1 serotyping was determined by the ratio of the highest OD value to the second highest OD value read from the four dengue virus serotypes. Positive serotype specificity is defined if the OD ratio is $\geq 1.2$, and negative serotype specificity is defined if the OD ratio is $<1.2$. Based on the NS1 serotype-specific IgG ELISA, primary dengue virus infection was defined if (i) a negative NS1-specific IgG antibody response was found for sera collected between days 1 and 14 of illness or (ii) a positive serotype specificity was found for sera collected after $\geq 9$ days of illness. Secondary dengue virus infection was defined if (i) a positive NS1-specific IgG antibody response was found for sera collected between days 1 and 8 of illness or (ii) a positive NS1-specific IgG antibody response and negative serotype specificity was found at any time after the onset of symptoms ${ }^{[13]}$. DEN-2, DEN-3, and DEN-4 infections of children patients in the study were confirmed by virus isolation and/or RT/PCR performed at the Pasteur Institute- HCM City and CDC, Department of Health, Taipei, Taiwan.

Detection of autoantibodies in the acute blood samples of the patients by flow cytometry: Human peripheral blood was mixed with $0.11 \mathrm{M}$ sodium citrate (9:1) and centrifuged at $100 \times \mathrm{g}$ for $10 \mathrm{~min}$ at room temperature. The upper layer as platelet-rich plasma was removed to a $15-\mathrm{mL}$ tube, mixed with $0.34 \%$ EDTA in phosphate-buffered saline (PBS), and centrifuged at $1000 \times \mathrm{g}$ for $10 \mathrm{~min}$. The pellets were washed 3 times with $0.34 \%$ EDTA in PBS and fixed in $10 \mathrm{ml}$ of $1 \%$ formaldehyde in PBS at room temperature for $10 \mathrm{~min}$. The fixed platelet suspension was centrifuged at $1000 \times \mathrm{g}$ for $10 \mathrm{~min}$ at room temperature. The pellets were washed in PBS twice and resuspended in $2 \mathrm{~mL}$ of PBS. For the assay, $2.5 \times 10^{6}$ platelets were incubated with various dilutions of patient or control serum for $1 \mathrm{~h}$ on ice, then washed twice with PBS. The secondary antibodies, i.e., $10 \mu \mathrm{L}$ of FITC-conjugated goat anti-human IgG or FITC-conjugated goat antihuman IgM monoclonal antibody (Sigma C., St Louise, USA), were added and the mixture was incubated for 40 min on ice. After washing twice with PBS, the platelets were resuspended in PBS and analyzed by flow cytometry (FACScan, Becton Dickinson, Mountain View, CA) with excitation set at $488 \mathrm{~nm}^{[12]}$. For detection of anti-endothelial cell autoantibodies, the endothelial cells (human microvascular endothelial cell line, HUMEC-1, CDC, Atlanta, GA) were suspended at $5 \times 10^{5}$ cells for flow cytometry. Cells were washed briefly with PBS and fixed with $1 \%$ formaldehyde in PBS at room temperature for $10 \mathrm{~min}$, then washed again with PBS. Patient sera were incubated with cells 
at $4^{\circ} \mathrm{C}$ for $1 \mathrm{~h}$. After washing three times with PBS, cells were incubated with $5 \mu \mathrm{L}$ of FITC-conjugated goat anti-human IgG or IgM (Sigma C., St Louise, USA) at $4^{\circ} \mathrm{C}$ for $1 \mathrm{~h}$. The binding activity of antibodies to endothelial cells was analyzed by flow cytometry (FACScan; Becton Dickinson, Mountain View, CA) with excitation set at $488 \mathrm{~nm}^{[11]}$.

Determination of serum levels of thrombomodulin (TM): Serum levels of TM (a maker for in vivo endothelial cell injury) of the patients were measured by use of the commercial IMUBIND ${ }^{\circledR}$ Thrombomodulin ELISA Kit (American Diagnostica Inc, CT). The laboratory method used and the interpretation of result for the kit were followed the manufacturer's instructions. Detection of anti-platelet and anti-endothelial cell autoantibodies by flow cytometry, and determinations of TM levels of the patient samples were performed at the Departments of Microbiology and Immunology, and Medical Technology of Medical College, National Cheng Kung University, Tainan, Taiwan.

Data and statistical analysis: The statistical significance of differences was compared using the Kruskal-Wallis for two groups. Statistical analyses were performed with Epi Info 2000 version 1.1 (CDC, USA). Differences with values of $p<0.05$ were considered significant.

\section{RESULTS}

All 50 infants except one suffered from primary dengue infections and only one remainder had secondary dengue infection based on E/M-specific capture IgM and IgG ELISA. In contrast to infants, almost children (33 out of $37,89.2 \%$ ) in the study suffered from secondary dengue infections, while 4 $(10.8 \%)$ remainders had primary dengue infections. Based on the NS1 serotype-specific IgG ELISA, there were 10 infants infected with DEN-3, and 4 with DEN4. Virus isolation and/or RT/PCR were positive in 17 out of 37 children, in which 3 children were infected with DEN-2, and 14 with DEN-4. Some clinical features of the patients are presented in the Table 1.

Table 1: Clinical features of DHF/DSS patients in the study

\begin{tabular}{|c|c|c|c|c|}
\hline Features & All patients & Non-shock DHF & DSS & $\mathrm{P}$ \\
\hline Infants & $\mathrm{n}=50$ & $\mathrm{n}=36$ & $\mathrm{n}=14$ & \\
\hline Age, mean $\% \pm$ SD & $7 \pm 2.5$ & $6.5 \pm 2.6$ & $8.2 \pm 1.7$ & 0.04 \\
\hline (range) (month). & $(1-11)$ & $(1-11)$ & $(1-11)$ & \\
\hline Sex, males/females & $29 / 21$ & $20 / 36$ & $9 / 14$ & \\
\hline \multirow{4}{*}{$\begin{array}{l}\text { Lowest platelet count, mean } \\
\times 10^{3} / \mathrm{mm}^{3} \pm \mathrm{SD} \text {, (range). } \\
\text { Increase in hematocrit, } \\
\text { mean } \% \pm \mathrm{SD} \text {, } \\
\text { (range). } \\
\quad(11-80)\end{array}$} & & & & \\
\hline & $52.6 \pm 26.7$ & $55.2 \pm 28.6$ & $46.2 \pm 20.8$ & 0.2 \\
\hline & $(14-121)$ & $(14-121)$ & $(20-100)$ & \\
\hline & $\begin{array}{l}41.5 \pm 17.9 \\
(11-80)\end{array}$ & $\begin{array}{l}38.1 \pm 16.7 \\
(21-80)\end{array}$ & $49.8 \pm 18.5$ & 0.04 \\
\hline \multirow{7}{*}{$\begin{array}{l}\text { Children } \\
\text { Age, mean } \% \pm \mathrm{SD} \text {, } \\
\text { (range) (year). } \\
\text { Sex, males/females } \\
\text { Lowest platelet count, mean } \\
\times 10^{3} / \mathrm{mm}^{3} \pm \mathrm{SD} \text {, } \\
\text { (range). } \\
\text { Increase in hematocrit, } \\
\text { mean } \% \pm \mathrm{SD} \text {, } \\
\text { range) }\end{array}$} & & & & \\
\hline & $\mathrm{n}=37$ & $\mathrm{n}=27$ & $\mathrm{n}=10$ & \\
\hline & $9.6 \pm 3.0$ & $10.2 \pm 2.9$ & $8.2 \pm 2.8$ & 0.06 \\
\hline & $\begin{array}{l}(4-15) \\
22 / 15\end{array}$ & $\begin{array}{l}(4-15) \\
15 / 12\end{array}$ & $\begin{array}{l}(4-13) \\
7 / 3\end{array}$ & \\
\hline & $67.7 \pm 38.5$ & $746+392$ & $487+310$ & \\
\hline & $(10-160)$ & $(20-160)$ & $(10-90)$ & 0.1 \\
\hline & $\begin{array}{l}32.8 \pm 12.9 \\
(11-59)\end{array}$ & $\begin{array}{l}30.4 \pm 13.1 \\
(11-50)\end{array}$ & $\begin{array}{l}39.3 \pm 10.0 \\
(28-59)\end{array}$ & 0.08 \\
\hline
\end{tabular}

Table 2: Levels of anti-platelet autoantibodies in infants and children with DHF/DSS

\begin{tabular}{|c|c|c|c|c|c|}
\hline $\begin{array}{l}\% \text { of platelets reactive } \\
\text { with autoantibodies }\end{array}$ & $\begin{array}{l}\text { All patients } \\
\text { mean\% } \% \text { SD } \\
\text { (range) }\end{array}$ & $\begin{array}{l}\text { Non- shock } \\
\text { DHF }\end{array}$ & DSS & Control & $\mathrm{P}$ \\
\hline $\begin{array}{l}\text { Infants } \\
\text {. }\end{array}$ & $(\mathrm{n}=50)$ & $(\mathrm{n}=36)$ & $(\mathrm{n}=14)$ & $(\mathrm{n}=10)$ & \\
\hline $\operatorname{IgM}$ & $\begin{array}{l}16.5 \pm 8.6 \\
(3.3-33.3)\end{array}$ & $\begin{array}{l}16.3 \pm 8.6 \\
(3.3-33.3)\end{array}$ & $\begin{array}{l}15.6 \pm 8.8 \\
(3.3-33.3)\end{array}$ & $\begin{array}{l}1.5 \pm 1.2 \\
(0.5-4.8)\end{array}$ & $\begin{array}{l}<0.001^{(\mathrm{a})} \\
0.7^{(\mathrm{b})}\end{array}$ \\
\hline $\begin{array}{l}\text { IgG } \\
\text { Children }\end{array}$ & $\begin{array}{l}3.4 \pm 1.3 \\
(1.1-7.9) \\
(n=36)\end{array}$ & $\begin{array}{l}3.4 \pm 1.2 \\
(1.1-5.6) \\
(n=26)\end{array}$ & $\begin{array}{l}3.4 \pm 1.7 \\
(1.1-7.9) \\
(n=10)\end{array}$ & $\begin{array}{l}1.5 \pm 0.5 \\
(1.0-2.6) \\
(n=7)\end{array}$ & $\begin{array}{l}<0.001^{(\mathrm{a})} \\
0.5^{(\mathrm{b})}\end{array}$ \\
\hline IgM & $\begin{array}{l}11.0 \pm 8.2 \\
(2.8-38.9)\end{array}$ & $\begin{array}{l}12.3 \pm 8.9 \\
(2.9-38.9)\end{array}$ & $\begin{array}{l}7.4 \pm 4.6 \\
(2.8-17)\end{array}$ & $\begin{array}{c}3.2 \pm 1.0 \\
(1.9-4.7)\end{array}$ & $\begin{array}{r}<0.001^{(\mathrm{a})} \\
0.09^{(\mathrm{b})}\end{array}$ \\
\hline $\mathrm{IgG}$ & $\begin{array}{l}4.2 \pm 4.9 \\
(1.1-28.3)\end{array}$ & $\begin{array}{l}2.8 \pm 1.4 \\
(1.1-7)\end{array}$ & $\begin{array}{l}7.8 \pm 8.2 \\
(1.6-28.3)\end{array}$ & $\begin{array}{l}4.3 \pm 1.7 \\
(1.8-6.4)\end{array}$ & $\begin{array}{l}0.1^{(\mathrm{a})} \\
0.008^{(\mathrm{b})}\end{array}$ \\
\hline
\end{tabular}

(a) P-values of comparison of between all DHF/DSS patients and controls by using Kruskal-Wallis test.

(b) P-value of comparison between non-shock DHF and DSS groups by using Kruskal-Wallis test. 


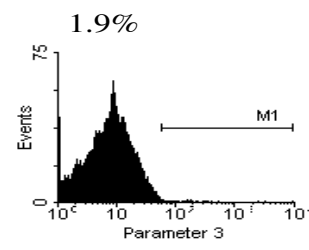

(A) Anti-platelet IgM in infant control

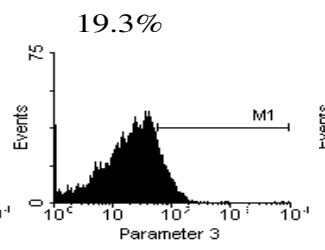

(B) Anti-platelet IgM in DHF/DSS infant

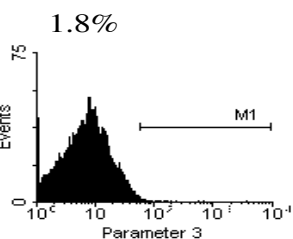

(C) Anti-platelet IgG in infant control

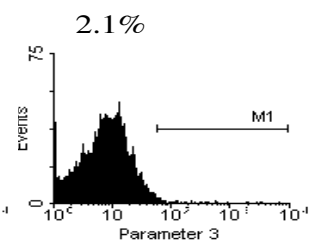

(D) Anti-platelet IgG in DHF/DSS infant

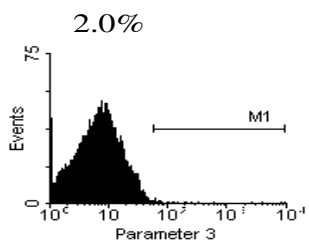

(E) Anti-platelet IgM in children control

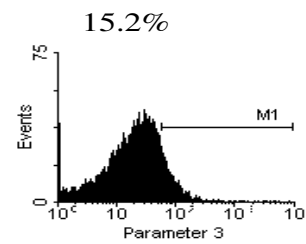
(F) Anti-platelet IgM
in DHF/DSS children
$2.6 \%$

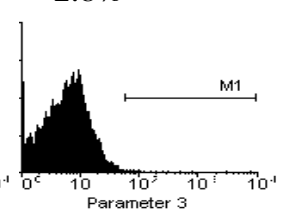

(G) Anti-platelet IgG in children control

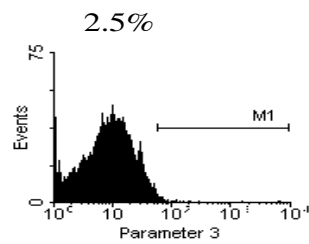

(H) Anti-platelet IgG in DHF/DSS children

Fig. 1: DHF/DSS infants and children produced IgM anti-platelet autoantibodies. Human platelets were incubated with 1:25 dilution of patient or normal control sera, followed by FITC-conjugated anti-human IgM or IgG and analyzed by flow cytometry. One example was presented

In this research we determined the binding activity of the patient's sera with platelets of normal healthy infants and children by using the flow cytometry. The sera of 10 healthy infants and 7 healthy children in control groups were tested to determine anti-platelet IgM and IgG levels. FITCconjugated anti-human IgM and IgG were used as the secondary antibody in flow cytometric analysis. There was an increase in the platelet binding activities when the infants and children's sera were tested, compared with control groups (IgM, mean, infants: $16.5 \%$ vs controls: $1.5 \%$, $\mathrm{p}<0.001$; and children: $11.0 \%$ vs controls: $3.2 \%$, $\mathrm{p}<0.001$ ) (Table 2). The isotype of these anti- platelet autoantibodies was mainly IgM in infants; the isotype $\operatorname{IgG}$ was also detected but with very low levels in infants (Table 2). The isotype of the anti-platelet antibodies was IgM but not IgG in children. Figure 1 illustrates a set of representative data. There was no difference in the percentage of platelets reactive with anti-platelet $\operatorname{IgM}$ in the sera of infants and children with non-shock DHF, compared with DSS patients $(\mathrm{p}=0.7$, and $\mathrm{p}=$ 0.09 , respectively) (Table 2). Linear regression analysis showed that there was no correlation between the anti-platelet $\operatorname{IgM}$ levels with the lowest platelet counts both in infants and children with DHF/DSS (data not shown).

Table 3: Levels of anti-endothelial cell autoantibodies in infants and children with DHF/DSS.

\begin{tabular}{|c|c|c|c|c|c|}
\hline $\begin{array}{l}\% \text { of HUMEC- } 1 \\
\text { (a) reactive with } \\
\text { autoantibodies }\end{array}$ & $\begin{array}{l}\text { All patients } \\
\text { mean\% } \% \text { SD } \\
\text { (range) }\end{array}$ & $\begin{array}{l}\text { Non-shock } \\
\text { DHF }\end{array}$ & DSS & Control & $\mathrm{P}$ \\
\hline Infants & $(\mathrm{n}=20)$ & $(n=12)$ & $(n=8)$ & $(n=4)$ & $0.003^{(b)}$ \\
\hline $\operatorname{IgM}$ & $\begin{array}{l}17.6 \pm 10.5 \\
(5.3-50.8)\end{array}$ & $\begin{array}{c}17.4 \pm 12.0 \\
(5.3-50.8)\end{array}$ & $\begin{array}{l}17.8 \pm 8.4 \\
(5.7-30.9)\end{array}$ & $\begin{array}{l}4.0 \pm 1.9 \\
(2.1-6.8)\end{array}$ & $\begin{array}{l}0.6^{(\mathrm{c})} \\
0.1^{(\mathrm{b})}\end{array}$ \\
\hline $\mathrm{IgG}$ & $\begin{array}{l}12.6 \pm 11.5 \\
(1.8-41.1)\end{array}$ & $\begin{array}{l}11.5 \pm 7.1 \\
(1.8-28.6)\end{array}$ & $\begin{array}{l}14.5 \pm 16.5 \\
(2-41.1)\end{array}$ & $\begin{array}{l}5.3 \pm 3.6 \\
(1.1-8.9)\end{array}$ & $0.5^{(\mathrm{c})}$ \\
\hline Children & $(\mathrm{n}=33)$ & $(\mathrm{n}=24)$ & $(n=9)$ & $(n=5)$ & \\
\hline IgM & $\begin{array}{l}46.0 \pm 15.3 \\
(4.6-72.9)\end{array}$ & $\begin{array}{l}50.2 \pm 12.5 \\
(8.7-72.9)\end{array}$ & $\begin{array}{l}35.0 \pm 17.4 \\
(4.6-52.5)\end{array}$ & $\begin{array}{l}4.7 \pm 0.5 \\
(4.2-5.3)\end{array}$ & $\begin{array}{l}<0.001^{(\mathrm{b})} \\
0.006^{(\mathrm{c})}\end{array}$ \\
\hline $\operatorname{IgG}$ & $\begin{array}{l}25.1 \pm 8.5 \\
(16-55.7)\end{array}$ & $\begin{array}{l}25.6 \pm 8.0 \\
(16-55.7)\end{array}$ & $\begin{array}{l}23.9 \pm 10.1 \\
(17.5-49.6)\end{array}$ & $\begin{array}{l}2.6 \pm 0.5 \\
(2.0-3.2)\end{array}$ & $\begin{array}{l}<0.001^{(\mathrm{b})} \\
0.1^{(\mathrm{c})}\end{array}$ \\
\hline
\end{tabular}




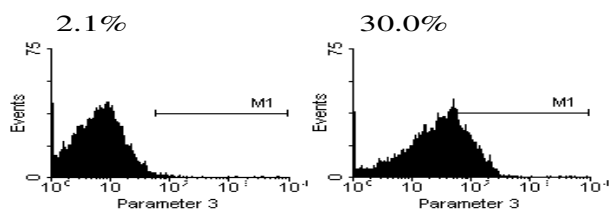

(A) Anti-EC IgM in infant control

(B) Anti-EC IgM in DHF/DSS infant

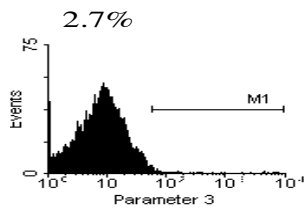

(C) Anti-EC IgG in infant control

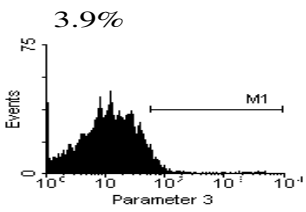

(D) Anti-EC IgG in DHF/DSS infant
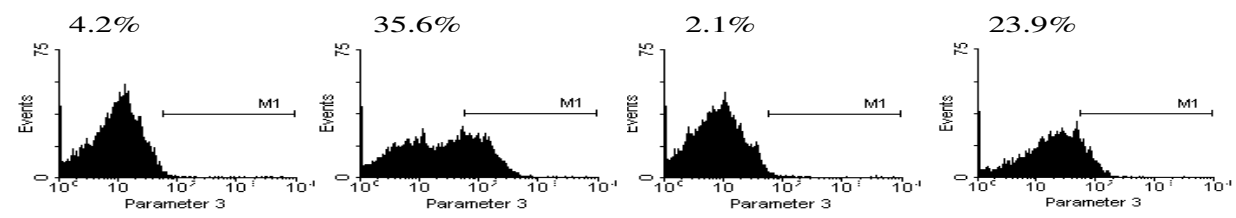

(E) Anti-EC IgM

(F) Anti-EC IgM in DHF/DSS children

(G) Anti-EC IgG in children control

(H) Anti-EC IgG in DHF/DSS children

Fig. 2: DHF/DSS infants and children produced anti-endothelial cell autoantibodies. Human microvascular endothelial cell line (HUMEC-1) were incubated with 1:25 dilution of patient or normal control sera, followed by FITC-conjugated anti-human $\operatorname{IgM}$ or IgG and analyzed by flow cytometry. One example was presented

Results revealed that when anti-human $\operatorname{IgM}$ or antihuman IgG was used as a secondary antibody, the binding reactivities of the sera of DHF/DSS infants with endothelial cells were detected by flow cytometric analysis. The isotype of anti-endothelial cell antibodies was mainly IgM; and the levels of anti-endothelial cell IgM in the sera of DHF/DSS infants were higher than in that of control group (mean, infants: $17.6 \%$ vs controls: $4.0 \%, \mathrm{p}=0.003)$. The level of $\mathrm{IgG}$ is not significantly different from controls (Table 3). Similarly, results showed that anti-endothelial cell binding activity of DHF/DSS children sera were higher than that of controls. In contrast to infants the isotype of anti-endothelial cell antibodies in DHF/DSS children were both $\operatorname{IgM}$ and $\operatorname{IgG}$ (mean, IgM, patients: $46.0 \%$ vs controls: $4.7 \%, \mathrm{p}<0.001$; IgG, patients: $25.1 \%$ vs controls: $2.6 \%, \mathrm{p}<0.001$ ) (Table 3). The levels of anti-endothelial cell antibodies were not different between non-shock DHF and DSS in infants as well as in children. A set of representative data is illustrated in Fig. 2. There was no relation between the levels ofanti-endothelial cell autoantibodies and the increase in hematocrit, an evidence of plasma leakage based on the linear regression analysis. Further analysis demonstrated that anti-platelet and anti-endothelial cellIgM or IgG levels were not different in children with primary and secondary dengue infections (Table 4).

Results showed that sera from infants infected with DEN-3 or DEN-4; and sera from children infected with
Table 4:Levels of anti-platelet and anti-endothelial cell autoantibodies in DHF/DSS infants with primary dengue infections, and in children with primary and secondary dengue infections

$\%$ of platelet/ HUMEC-1 Primary

reactivewith autoantibodies infections Secondary mean $\% \pm \mathrm{SD}$, infections (range)

$\mathrm{P}^{(\mathrm{a})}$

Anti-platelet autoantibody:

*Infants,

$(\mathrm{n}=49)$

$\operatorname{IgM}$

$16.5 \pm 8.6$

*Children,

IgM

$(3.3-33.3)$

$(\mathrm{n}=3) \quad(\mathrm{n}=33)$

$8.7 \pm 3.1 \quad 11.2 \pm 8.5$

$(6.9-12.4) \quad(2.8-38.9)$

Anti-endothelial cell autoantibody:

*Infants,

$(\mathrm{n}=20)$

IgM

$17.6 \pm 10.5$

*Children,

IgM

$(5.3-50.8)$

IgG

$(\mathrm{n}=4)$

$(\mathrm{n}=29)$

$46.3 \pm 10.6 \quad 46.0 \pm 16.0$

$(33.2-56.2) \quad(4.6-72.9)$

$25.3 \pm 4.4 \quad 25.1 \pm 8.9 \quad 0.5$

$(22.2-31.6) \quad(16-55.7)$

(a): P-values of comparison between children with primary and secondary dengue infections by using Kruskal-Wallis test

DEN-2 or DEN-4 had anti-platelet IgM. The levels of anti-platelet IgM were similar between the patients infected with different dengue serotypes (Table 5). Anti-endothelial cell $\mathrm{IgM} / \mathrm{IgG}$ autoantibodies were detected in both groups of children infected with DEN-2, and DEN-4; and the levels of these autoantibodies were not different between those two groups. 


\begin{tabular}{|c|c|c|}
\hline & $\begin{array}{l}\% \text { of platelets/ HUMEC } \\
\text { reactive with autoantibodies } \\
\text { mean } \pm \text { SD (range) }\end{array}$ & $\mathrm{P}$ \\
\hline \multicolumn{3}{|l|}{$\begin{array}{l}\text { DHF/ DSS infants, } \\
\text { *Anti-platelet IgM: }\end{array}$} \\
\hline DEN-3 infections $(n=10)$ & & $0.7^{(\mathrm{a})}$ \\
\hline DEN-4 infections $(n=4)$ & $15.0 \pm 7.6(3.3-28.4)$ & \\
\hline $\begin{array}{l}\text { *Anti-endothelial cell IgM: } \\
\text { DEN-3 infections }(\mathrm{n}=6)\end{array}$ & $13.6 \pm 4.8(6.7-17.0)$ & \\
\hline $\begin{array}{l}\text { DHF/ DSS children, } \\
\text { *Anti-platelet IgM: }\end{array}$ & $13.7 \pm 8.0(5.3-26.8)$ & \\
\hline DEN-2 infections $(n=3)$ & & $1^{(\mathrm{a})}$ \\
\hline DEN-4 infections $(n=14)$ & $7.0 \pm 1.4(5.3-7.9)$ & \\
\hline $\begin{array}{l}\text { *Anti-endothelial cell IgM: } \\
\text { DEN-2 infections }(\mathrm{n}=3)\end{array}$ & $8.5 \pm 4.7(2.9-19.3)$ & \\
\hline DEN-4 infections $(n=14)$ & $36.5 \pm 27.6(4.6-52.6)$ & $0.7^{(\mathrm{a})}$ \\
\hline *Anti-endothelial cell IgG: & $44.4 \pm 13.7(8.7-63.5)$ & \\
\hline DEN-2 infections $(n=3)$ & & $0.6^{(a)}$ \\
\hline DEN-4 infections $(\mathrm{n}=14)$, & $\begin{array}{l}24.1 \pm 2.3(21.4-25.8) \\
26.5 \pm 9.4(18.3-55.7)\end{array}$ & \\
\hline
\end{tabular}

Table 6: Plasma levels of thrombomodulin in infants and children with DHF/DSS

\begin{tabular}{|c|c|c|c|c|c|}
\hline $\begin{array}{l}\text { Thrombomod } \\
\text { mean } \\
\text { pg mL } \mathrm{mL}^{-1} \pm \mathrm{SD} \text {, } \\
\text { (range) }\end{array}$ & All patients & $\begin{array}{l}\text { Non-shock } \\
\text { DHF }\end{array}$ & DSS & Control & $\mathrm{P}$ \\
\hline \multirow[t]{2}{*}{ Infants } & $(\mathrm{n}=24)$ & $(\mathrm{n}=14)$ & $(\mathrm{n}=10)$ & $(\mathrm{n}=10)$ & \\
\hline & $\begin{array}{l}6.11 .7 \pm \\
(2.8-9.7)\end{array}$ & $\begin{array}{l}6.3 \pm 1.0 \\
(4.1-8.5)\end{array}$ & $\begin{array}{l}5.8 \pm 2.3 \\
(2.8-9.7)\end{array}$ & $\begin{array}{l}2.7 \pm 0.4 \\
(2.2-3.8)\end{array}$ & $\begin{array}{c}<0.001^{(\mathrm{a})} \\
0.2^{(\mathrm{b})}\end{array}$ \\
\hline Children & $\begin{array}{l}(\mathrm{n}=34) \\
8.8 \pm 2.1 \\
(5.5-15.5)\end{array}$ & $\begin{array}{l}(\mathrm{n}=25) \\
9.0 \pm 2.3 \\
(5.5-15.5)\end{array}$ & $\begin{array}{l}(\mathrm{n}=9) \\
8.2 \pm 1.2 \\
(6.3-10.3)\end{array}$ & $\begin{array}{l}(\mathrm{n}=2) \\
2.4 \pm 0.06 \\
(2.4-2.5)\end{array}$ & $\begin{array}{ll}6 & 0.01^{(\mathrm{a})} \\
& 0.4^{(\mathrm{b})}\end{array}$ \\
\hline $\begin{array}{l}\text {-valu } \\
\text { contrc }\end{array}$ & & & & & \\
\hline
\end{tabular}

(Table 5). Serum levels of TM were determined in the acute samples of 24 infants and 34 children. Serum levels of TM in infants and children with DHF/DSS were higher than those of controls (mean, infants: $6.1 \mathrm{pg} \mathrm{mL}^{-1}$ vs controls: $2.7 \mathrm{pg} \mathrm{mL}^{-1}, \mathrm{p}<0.001$, children: $8.8 \mathrm{pg} \mathrm{mL}^{-1}$ vs controls: $2.4 \mathrm{pg} \mathrm{mL}^{-1}, \mathrm{p}=$ 0,01) (Table 6). However, TM levels was not correlated with the severity of DHF in infants and children (non-shock DHF vs DSS) $(\mathrm{p}=0.2$, and $\mathrm{p}=0.4)$ (Table 6). There was no correlation between the serum levels of TM and levels of anti-endothelial cell autoantibodies as well as the increase in hematocrit in infants and children with DHF/DSS (data not shown).

\section{DISCUSSION}

The present study verified the presence of antiplatelet and anti-endothelial cell autoantibodies in two different groups of DHF/DSS patients, infants and children with predominantly primary and secondary dengue infections, respectively, in an endemic region of dengue virus infections.

Thrombocytopenia is an important finding in DHF/DSS. Multiple factors may be involved in the mechanisms leading to thrombocytopenia in DHF/DSS patients. Impairment of hematopoietic progenitor cell growth caused by dengue virus resulting in thrombocytopenia was reported ${ }^{[15]}$. Another cause of thrombocytopenia was due to consumptive coagulopathy ${ }^{[16]}$. The detection of anti-platelet autoantibodies in Taiwanese children and adults with dengue infections showed that autoantibodies which cross-reacted with platelets may account for thrombocytopenia in dengue patients ${ }^{[12]}$. The present study is the first to demonstrate the presence of antiplatelet autoantibodies in DHF/DSS infants with primary dengue infections; it also confirms the presence of these autoantibodies in DHF/DSS children with predominantly secondary dengue infections. The isotype of these autoantibodies is IgM in both infants and children. The levels of these autoantibodies were not different between patients with non-shock DHF and DSS, nor between patients with primary and secondary dengue infections. Lin et al. found that the levels of anti-platelet autoantibodies were higher in patients with DHF/DSS than those in patients with DF; however, the correlation between the levels of these autoantibodies and the platelet count could not be performed due to the limit of number of patients ${ }^{[12]}$. In our study we noted that there was no correlation between the levels of $\operatorname{IgM}$ autoantibodies with the lowest platelet counts both in infants and children with DHF/DSS based on linear regression analysis. J. van der Lelie et al. reported the detection of anti-platelet autoantibodies in $38 \%$ of acute sera and in $43 \%$ of the post- treatment sera of patients with septicemia; these antibodies seemed depending partially or completely on EDTA ${ }^{[17]}$. From this observation the authors suggested a hypothesis that these antibodies mainly cross-reacted with cryptantigens expressed on the surface of the platelets which had been damaged in vivo due to septicemia, and 
in vitro due to the presence of $\operatorname{EDTA}^{[17]}$. This hypothesis could explain the observation that the levels of autoantibodies was not correlated with the platelet counts in septic patients. In our study we found no relation between the levels of anti-platelet autoantibodies and the severity of DHF (non-shock DHF vs DSS), nor between the levels of autoantibodies and the platelet counts. It is speculated that in the acute phase of DHF/DSS those platelets expressed with specific surface molecules are recognized by the autoantibodies and subsequently lysed. Flow cytometric analysis supported this hypothesis since only some subpopulations of the platelets of normal people could cross-react with the autoantibodies in the patient sera.

In the report of Lin et al., sera from 9 patients with DEN-3 infections were studied and demonstrated the presence of anti-platelet IgM autoantibodies ${ }^{[12]}$. In our study, we found that sera from 10 infants infected with DEN-3, and 4 with DEN-4 had anti-platelet IgM. Furthermore, sera from 3 children with DEN-2 infections, and 14 with DEN-4 had also tested showing they contained anti-platelet IgM (Table 5). These observations expressed that induction of anti-platelet IgM was unique finding in DHF/DSS patients infected with almost serotypes of dengue virus.

Previous studies using murine anti-NS1 antibodies showed their cross-reaction with human platelets $^{[18]}$. A recent report showed that the isotype of NS1-P1 (aminoacids 1-15)- specific antibodies was mainly $\operatorname{IgM}$ in all dengue patient sera that tested positive ${ }^{[19]}$. Therefore, it is speculated that the dengue virus antigens, for example, NS1 aminoacids 1-15 which possess B-cell epitope may induce IgM autoantibodies cross-reactive with platelets. The effects of the cross-reactive antibodies included both induction of platelet lysis and inhibition of platelet aggregation. Induction of platelet lysis may, at least in part, explain thrombocytopenia in the acute phase ${ }^{[12]}$. The epitopes shared by platelet surface molecules and dengue virus antigens need to be mapped and avoided in designing the safe candidate vaccines.

Increased vascular permeability is the hallmark of DHF/DSS. Understanding the mechanisms of increased vascular permeability resulting in plasma leakage would improve the management of the disease. A role played by autoantibodies in the pathogenesis of DHF/DSS has already been suggested ${ }^{[6,18]}$. This study demonstrated that DHF/DSS infants with primary dengue infections produced $\operatorname{IgM}$ antibodies which cross-reacted with the endothelial cells. In contrast to infants the isotype of anti-endothelial cell autoantibodies in DHF/DSS children with predominantly secondary dengue infections were both IgM and IgG. Their bindings were also higher than those of infants. This is probably due to either the more mature immune system of children than that of infant or the effect of immune memory in secondary infection. The pattern of endothelial cell autoantibodies in children in this study was similar with that from the children and adults in Lin et al.'s study in Taiwan ${ }^{[11]}$. The results of the present study showed that the antiendothelial activities of the patient sera were not different between non-shock DHF and DSS in infants and children, nor between patients with primary and secondary dengue infections. The autoantibodies that bound and induced endothelial cell apoptosis were reported in children and adults in the previous study ${ }^{[11]}$. The fact that the endothelial binding activity of dengue patient sera could be reduced by pretreatment with recombinant NS1, indicated that the epitopes recognized by patient sera are shared between the endothelial cell surface molecules and NS1 of dengue virus ${ }^{[11]}$. Furthermore, in the present study there was no correlation between the levels of anti-endothelial cell autoantibodies and the increase in hematocrit, an evidence of plasma leakage. It is speculated that in the acute phase of DHF/DSS those endothelial cells expressed with specific surface molecules could react with the autoantibodies. Whether surface molecules of endothelial cells recognized by the autoantibodies are similar or different with those of platelets need to be further investigated.

The most characteristic feature of DHF/DSS and the best indicator of disease severity is plasma leakage. Plasma leakage occurs systemically, progressing quickly, but will resolve within 1-2 days in patients who receive appropriate fluid resuscitation. No subsequent tissue or organ dysfunction is observed $^{[2,20,21]}$. It was previously thought that plasma leakage was due to altered vascular permeability rather than to structural destruction of endothelial cells. The functional alteration in endothelial cells is probably caused by standard effects of cytokine or mediator release in dengue infection. The dengue virus can infect endothelial cells in vitro which leads to the production of cytokines and chemokines such as IL-6, IL-8, and RANTES $^{[8,9,22]}$. Dengue virus-infected endothelial cells are capable of activating complement and inducing the 
expression of adhesion molecules such as ICAM- ${ }^{[6]}$. The expression of ICAM-1 together with the production of chemokines IL-8 and RANTES increases the adherence of polymorphonuclear cells and mononuclear cells, respectively, and results in increased vasopermeability and TM release, a marker of endothelial cell damage ${ }^{[6]}$. Results in our study showed elevated levels of TM in the sera of infants and children with DHF/DSS, compared with controls. These data indicated that endothelial cell structural damage did occur in vivo. Since endothelium plays a crucial role in maintaining hemostasis, damage of endothelial cells by dengue virus infection may skew the procoagulant/ anticoagulant balance of endothelium and increase the bleeding tendency. The sequestration of platelets by activated endothelial cells might also contribute to the development of thrombocytopenia ${ }^{[6]}$.

\section{CONCLUSION}

This study verified the presence of antibodies which cross-reacted with platelets, and endothelial cells in the sera of Vietnamese infants and children with DHF/DSS. These autoantibodies may play a role in the pathogenesis of DHF/DSS in infants and children with predominantly primary, and secondary dengue infections, respectively. To eradicate dengue virus infections the development of effective vaccines are mandatory; the findings in the present study stress that the epitopes shared by surface molecules of platelets and endothelial cells and dengue virus antigens need to be identified and avoided in designing the safe candidate vaccines.

\section{ACKNOWLEGEMENTS}

We thank Dr Tran Tan Tram, the Director of the Children's Hospital No.1-Ho Chi Minh City, and Prof Chung-Ming Chang, National Health Research Institutes, Taiwan for help and support during the course of this study. Thanks also to the doctors and nurses of the Department of Dengue Hemorrhagic Fever, Children's Hospital No.1-Ho Chi Minh City for providing excellent patient care. This work was supported partly by grant NHRI-CN-CL-8901P from the National Health Research Institutes, Taiwan.

\section{REFERENCES}

1. Gubler, D.J., 1998. Dengue and Dengue hemorrhagic fever. Clin. Microbiol. Rev., 11: 480-496.

2. World Health Organization, 1997. Dengue hemorrhagic fever: diagnosis, treatment, prevention and control. 2nd edition. Geneva: WHO.
3. World Health Organization, 2002. Dengue and Dengue hemorrhagic fever. Fact Sheet N.117, revised April, 2002.

4. Haltead, S.B., 1993. Pathophysiology and pathogenesis of Dengue hemorrhagic fever. In: WHO-Monograph on Dengue/Dengue hemorrhagic fever. New Delhi, pp: 80-103.

5. Rothman, A.L. and F.A. Ennis, 1999. Immunopathogenesis of dengue hemorrhagic fever. Virol., 257: 1-6.

6. Lei, H.Y., T.M. Yeh, H.S. Liu, Y.S. Lin, S.H. Chen and C.C. Liu, 2001. Immunopathogenesis of dengue virus infection. J. Biomed. Sci., 8: 377388.

7. Andrews, B.S., A.N. Theofilopoulos, C.J. Peters, D.J. Loskutoff, W.E. Brandt and F.J. Dixon, 1978. Replication of dengue and Junin viruses in cultured rabbit and human endothelial cells. Infect. Immun. 20: 776-781.

8. Avirutnan, P., P. Malasit, B. Seliger, S. Bhakdi and M. Husmann, 1998. Dengue virus infection of human endothelial cell leads to chemokine production, complement activation, and apoptosis. J. Immunol.,161: 6338-6346.

9. Huang, Y.H., H.Y. Lei, H.S. Liu, Y.S. Lin, C.C. Liu and T.M. Yeh, 2001. Dengue virus infects human endothelial cells and induces IL-6 and IL-8 production. Am. J. Trop. Med. Hyg., 63: 71-75.

10. Halstead, S.B, 1989. Antibody, macrophages, dengue virus infection, shock, and hemorrhage: a pathogenic cascade. Rev. Infect. Dis., 11: S830 -839.

11. Lin, C.F., H.Y. Lei, A.L. Shiau, C.C. Liu, H.S. Liu, T.M. Yeh, S.H. Chen and Y.S. Lin, 2003. Antibodies from dengue patient sera cross-react with endothelial cells and induce. J. Med. Virol., 69: 82 - 90.

12. Lin, C,F., H.Y. Lei, C.C. Liu, H.S. Liu, T.M. Yeh, S.T. Wang, T.I. Yang, F.C. Sheu, C.F. Kuo and Y.S. Lin, 2001. Generation of IgM anti-platelet autoantibody in dengue patients. J. Med. Virol., 63: 143-149.

13. Shu, P.Y., L.K. Chen, S.F. Chang, Y.Y. Yueh, L. Chow, L.J. Chien, C. Chin, H.H. Yang, T.H. Lin and J.H. Huang, 2003. Comparison of capture immunoglobulin M (IgM) and IgG enzyme-linked immunosorbent assay (ELISA) and nonstructural protein NS1 serotype-specific IgG ELISA for differentiation of primary and secondary dengue virus infections. Clin. Diag. Lab. Immunol., 10: 622-630.

14. Hung, N.T., H.Y. Lei, N.T. Lan, Y.S. Lin, K.J. Huang, L.B. Lien, C.F. Lin, T.M. Yeh, D.Q. Ha, V.T.Q. Huong, L.C. Chen, J.H. Huang, L.T. My, C.C. Liu and S.B. Halstead, 2004. Dengue hemorrhagic fever in infants: a study on clinical and cytokine profiles. J. Infect. Dis. 189: 221-232. 
15. Murgue, B., O. Cassar, M. Guigon and E. Chungue, 1997. Dengue virus inhibits human hematopoietic progenitor growth in vitro. J. Infect. Dis., 175: 1497-1501.

16. Srichaikul, T. and S. Nimmannitya, 2000. Haematology in dengue and dengue hemorrhagic fever. Bailliere's Clin. Haematol., 13: 261-274.

17. van der Lelie, J., C.N. van der Plas-Van dalen and A.E.G. Kr. Von dem Borne, 1984. Platelets autoantibodies in septicaemia. Brit. J. Hematol., 58: 755-760.

18. Falconar, A.K.I., 1997. The dengue virus nonstructural-1 protein (NS1) generates antibodies to common epitopes on human blood clotting, intergrin/adhesin proteins and binds to human endothelial cells: potential implications in hemorrhagic fever pathogenesis. Arch. Virol., 142: 897-916.
19. Huang, J.H., J.J. Wey, Y.C. Sun, C. Chin, L.J. Chien and Y.C. Wu, 1999. Antibody responses to an immunodominant nonstructural 1 synthetic peptide inpatients with dengue fever and dengue hemorrhagic fever. J. Med. Virol., 57: 1-8.

20. Nimmannitya, S., 1987. Clinical spectrum and managemnet of dengue hemorrhagic fever. Southeast Asia. J. Trop. Med. Publ. Heal., 18: 392-397.

21. Nimmannitya, S., 1997. Dengue hemorrhagic fever: diagnosis and management. In: Gubler DJ, Kuno G, editors. Dengue and Dengue hemorrhagic fever. Wallingford, UK: CAB International, pp: 133 - 146.

22. Anderson, R., S. Wang, C. Osiwy, A.C. Issekutz, 1997. Activation of endothelial cells via antibodyenhanced dengue virus infection of peripheral blood monocytes. J. Virol., 71: 4226-4232. 